\title{
Analysis of Influencing Factors and Mechanism of Strength of Cement-Modified Silty Sand
}

\author{
Weidong Jin $\mathbb{D},{ }^{1}$ Zhe Wang, ${ }^{1}$ Yongming Ai $\mathbb{D}^{1},{ }^{1}$ and Chenyang Liu $\mathbb{D}^{2}$ \\ ${ }^{1}$ Transportation College of Jilin University, Jilin University, Changchun 130000, China \\ ${ }^{2}$ College of Construction and Engineering, Jilin University, Changchun 130000, China \\ Correspondence should be addressed to Yongming Ai; jilindx@126.com and Chenyang Liu; chenyangl19@mails.jlu.edu.cn
}

Received 19 April 2021; Revised 13 October 2021; Accepted 21 October 2021; Published 1 November 2021

Academic Editor: Xudong Zhang

Copyright (C) 2021 Weidong Jin et al. This is an open access article distributed under the Creative Commons Attribution License, which permits unrestricted use, distribution, and reproduction in any medium, provided the original work is properly cited.

\begin{abstract}
The unconfined compressive strength of cement-modified silty sand in Jilin Province was investigated in this study. For this purpose, various tests were conducted, including the screening test, compaction test, CBR test, X-ray fluorescence detection, and unconfined compressive strength test. Effects of compaction degree, soil quality, water quality, cement content, and curing age were considered. The results show that CBR value is positively correlated with compactness. Two kinds of different water qualities have little effect on unconfined compressive strength of cement-improved soil; with the increase in cement content, the unconfined compressive strength increases, and the power function equation established by the two is significantly correlated. The logarithmic relationship between cement-soil strength and curing age is approximately linear. Through regression analysis, the comprehensive characterization parameters of cement-soil strength, such as water-cement ratio, cement content, and curing age, are put forward. The unconfined compressive strength of cement-modified silty sand has a good power function relationship with the comprehensive characterization parameters, and the fitting degree between the strength prediction formula and the existing research and test data exceeds $90 \%$, which verifies the effectiveness of the comprehensive characterization parameters.
\end{abstract}

\section{Introduction}

In order to prevent roadbed diseases and improve roadbed strength, many scholars propose to use cement, lime, fiber, slag, and other materials to reinforce and improve roadbed soil $[1,2]$. The use of cement to dispose of roadbed soil has the advantages of obtaining local materials and convenient construction. It has been widely used in the treatment of foundation stabilization $[3,4]$. Silty sand has low natural water content, small plasticity index, and low shear strength. When the particles are fine, the capillary action is strong, and the migration and accumulation of water in a silty sand subgrade in a seasonal freezing area are obvious [5]. Cement-modified silt sand (hereinafter referred to as cement-modified soil) is a kind of hard material with special engineering characteristics, which is composed of soil as the main aggregate, Portland cement as the cementing material, and water as the reaction medium, after mixing, vibrating, and curing. It has the advantages of high compressive strength, frost resistance, imperme- ability, erosion resistance, and good durability [6, 7]. In order to prevent subgrade diseases and ensure subgrade strength, cement is used to reinforce subgrade soil in many sections of Shuangtao Expressway in Jilin Province.

At present, there are few systematic theories and applied researches on cement-modified silty sand. The research results of Liu et al. [8] show that the main factors affecting the strength of cement-improved soil are soil properties, cement types and dosage, curing age, and so on; Li et al. [9] quantitatively analyzed the influence of cement content, moisture content, and curing age on unconfined compressive strength through laboratory tests of cement-improved silt; Lei and Huang [10] explored the change of unconfined compressive strength of cement-modified silt sand with age under dry and wet cycles. The results showed that the strength first increased with the increase in curing age and reached the peak value in 7 days. Then, it decreases with increasing curing age; Yan [11] put forward that the unconfined compressive strength of cement-modified soil increases with the increase 
TABLe 1: Physical properties of silty sand.

\begin{tabular}{lccccc}
\hline Silty sand & Liquid limit wL (\%) & Plastic limit WP (\%) & Plasticity index IP & $\begin{array}{c}\text { Maximum dry density } \\
\left(\mathrm{g} / \mathrm{cm}^{3}\right)\end{array}$ & $\begin{array}{c}\text { Optimal moisture } \\
\text { content } W(\%)\end{array}$ \\
\hline Soil sample 1 & 22 & 16 & 6 & 1.83 & 6.7 \\
Soil sample 2 & 19 & 15 & 4 & 1.99 & 8.1 \\
\hline
\end{tabular}

in cement content and age, and the strength develops rapidly in the early stage and gradually slows down in the later stage; Chen [12] analyzed the influence law of the curing method, water saturation condition, and compaction degree on unconfined compressive strength of cement-modified soil, among which curing age had significant influence on strength, and the strength continued to increase with the increase in time. Zhang et al. $[13,14]$ proposed an improved water-heat coupling model to analyze the destruction process of soil under harsh environments such as cold and the prediction of freezing depth. Wu et al. $[15,16]$ deduced the coupling equations of water, heat, and deformation of frozen soil and verified the validity and applicability of the coupling equations by comparing the results of experiments and numerical simulations. Xu et al. $[17,18]$ effectively improved the mechanical properties of landfill sludge through the combination of vacuum preloading and physical or chemical methods. In view of the influencing factors of cement-modified soil strength, scholars domestically and internationally put forward some strength characterization parameters. Lorenzo and Bergado [19] think that the strength characteristics of cement-soil can be characterized by the ratio of cement-soil void to cement content; Chu et al. [20] analyzed the influence of water content, cement content, and curing age on the strength of cement-soil and defined the concept of the similar watercement ratio to predict the strength of cement-soil. Cao and Zhang [21] put forward a strength characterization parameter reflecting the cement content, curing age, and porosity.

In this paper, through the unconfined compressive strength test of cement-modified soil, the influence law of different soil samples, cement content, curing age, watercement ratio, and other parameters on the strength of cement-modified soil are analyzed, and the strength characterization parameters which are generally applicable to cement-modified soil are constructed to comprehensively reflect the change law of the influence of various influencing factors on the strength, and the empirical formula of strength prediction is established, so as to provide a theoretical basis and practical reference for the application and popularization of the cement-improved soil subgrade in seasonal frozen areas.

\section{Materials and Methods}

2.1. Test Material. Test soil samples are taken from different silty sand borrow yards along Shuangtao Expressway. Soil sample 1 comes from the borrow pit K132+640 of the fifth work area of the Shuangtao Project, and soil sample 2 comes from the borrow pit K21+640 of the first work area of the Shuangtao Project. Physical and mechanical properties of silty sand are shown in Table 1 . The particle grading curve

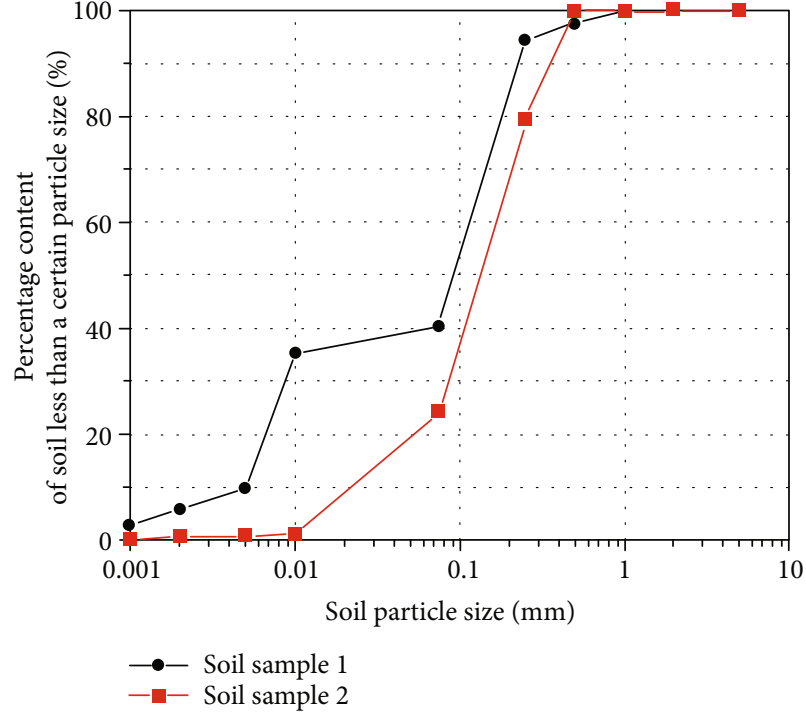

FIGURE 1: Silty sand grading curve.

is shown in Figure 1. Ordinary Portland cement SZS retarding -078 produced by Siping North Cement Co., Ltd. is selected as cement, and the physical performance indexes of cement are shown in Table 2. The optimal moisture content and maximum dry density of cement-modified soil with different cement contents are shown in Table 3.

It can be seen from Figure 1 that the particle size of the soil samples is mainly concentrated between 0.075 and $0.25 \mathrm{~mm}$. In the two soil sample components, the mass of the coarse-grained group is greater than $50 \%$ of the total soil mass, and the mass of the fine-grained group accounts for more than $15 \%$ and less than $50 \%$ of the total soil mass. The plasticity index of both soil samples is less than 10 . According to the "Test Methods of Soils for Highway Engineering" [22] and "Specifications for Design of Foundation of Highway Bridges and Culverts" [24], the soil sample can be defined as silty sand. The following are calculated from Figure 1: the uneven coefficient of soil sample $1\left(C_{\mathrm{u}}=27.6\right)$, the curvature coefficient $\left(C_{\mathrm{C}}=1.78\right)$, the uneven coefficient of soil sample $2\left(C_{\mathrm{u}}=5.4\right)$, and the curvature coefficient $\left(C_{\mathrm{C}}=2.65\right)$. Two different soil samples satisfy $C_{\mathrm{u}} \geq 5$ and $C_{\mathrm{C}}=1 \sim 3$ at the same time, indicating that the gradation of the soil is good and it is uneven soil. In order to further explore the chemical composition of the soil sample, the XRF (X-ray fluorescence) detection method is used to analyze the total silicate of the soil sample. XRF spectral analysis technology can be used to confirm the specific elements in the substance and quantify it at the same time. It can determine the specific element according to the emission wavelength $\lambda$ and energy $E$ of the X-ray and determine the 
TABle 2: Physical performance index of cement.

\begin{tabular}{|c|c|c|c|c|}
\hline \multirow{2}{*}{ Fineness (mm) } & \multicolumn{2}{|c|}{ Setting time $(\mathrm{min})$} & \multirow{2}{*}{ Stability } & \multirow{2}{*}{ Loss on ignitio } \\
\hline & Initial set & Final set & & \\
\hline 0.08 & 381 & 452 & Qualified & 2.11 \\
\hline \multicolumn{5}{|c|}{$\begin{array}{l}\text { TABLE 3: Optimum moisture content and maximum dry density of } \\
\text { cement-modified soil. }\end{array}$} \\
\hline $\begin{array}{l}\text { Cement mixing } \\
\text { amount }(\%)\end{array}$ & $\begin{array}{l}\text { Max } \\
\text { dens }\end{array}$ & $\begin{array}{l}\text { ximum dry } \\
\text { sity }\left(\mathrm{g} / \mathrm{cm}^{3}\right)\end{array}$ & & $\begin{array}{l}\text { ptimal moisture } \\
\text { content } W(\%)\end{array}$ \\
\hline 3 & & 1.91 & & 11.3 \\
\hline 4 & & 1.92 & & 11.5 \\
\hline 5 & & 1.92 & & 11.7 \\
\hline 6 & & 1.93 & & 12.0 \\
\hline
\end{tabular}

amount of this element by measuring the density of the corresponding ray. The silicate full analysis items include $\mathrm{SiO}_{2}$, $\mathrm{CaO}, \mathrm{MgO}, \mathrm{Fe}_{2} \mathrm{O}_{3}, \mathrm{FeO}, \mathrm{Al}_{2} \mathrm{O}_{3}, \mathrm{TiO}_{2}, \mathrm{P}_{2} \mathrm{O}_{5}, \mathrm{~K}_{2} \mathrm{O}, \mathrm{Na}_{2} \mathrm{O}$, $\mathrm{MnO}$, Los, etc. (12 items). The test process is shown in Figure 2 (take $\mathrm{SiO}_{2}$ as an example). In chemical composition, the analysis is shown in Table 4.

2.2. Experiment Design. The influence of soil quality, water quality, cement content, and curing age on the unconfined compressive strength of cement-improved soil was explored through the controlled variable method. The test plan is shown in Table 5, where the mixed soil samples are soil sample 1 and soil sample 2; it accounts for $50 \%$ of the total mass. The $\mathrm{pH}$ value of drinking water is 7.0. The soaking water is the clarified liquid of the water in the borrow yard, the soaking time is 12 hours, and the $\mathrm{pH}$ value is 9.5 .

\subsection{Experiment Method}

2.3.1. CBR Text. The test is carried out in accordance with the issued Code for Test Methods of Soils for Highway Engineering (JTG 3430-2020) [22]. The soil samples are dried, crushed, and sieved with a $5 \mathrm{~mm}$ round hole. Mix the sieved soil sample to the best moisture content, mix evenly, and stuff the material for $2 \mathrm{~h}$. Cement is added according to the dosage of $3 \%$ cement. The standard specimens were soaked for $96 \mathrm{~h}$ before the penetration test. The ratio of unit pressure to standard pressure when the penetration amount was $2.5 \mathrm{~mm}$ was used as the bearing ratio (CBR value) of cement-modified soil, and the bearing ratio when the penetration amount was $5 \mathrm{~mm}$ was calculated at the same time. If the bearing ratio of $5 \mathrm{~mm}$ was greater than that of $2.5 \mathrm{~mm}$, the test was carried out again. If the result is still the same, the bearing ratio of $5 \mathrm{~mm}$ was used as the CBR value of the cement soil.

2.3.2. Unconfined Compressive Strength Test. Evaluate the compressive strength of cement-modified soil in accordance with the unconfined compressive strength test method in "Test Methods of Materials Stabilized with Inorganic Binders for Highway Engineering" (JTG E51-2009) [23]. The size of the test mold is $\Phi 50 \mathrm{~mm} \times 50 \mathrm{~mm}$, and the sur- face is coated with petroleum jelly to facilitate demolding. After the sample is evenly stirred, it is loaded into the test mold in two layers and compacted. After standing for $4 \mathrm{~h}$, the specimens were demolded and put into the curing room with a curing temperature of $20 \pm 2^{\circ} \mathrm{C}$ and a relative humidity of more than $95 \%$ for constant temperature curing to the specified age. After reaching the curing age, use a universal testing machine to perform an unconfined compressive strength test with a loading rate of $1 \mathrm{~mm} / \mathrm{min}$. Prepare 6 samples of each kind, and calculate the average value, standard deviation, and coefficient of deviation after removing the abnormal value to obtain the standard value. The unconfined compressive test instrument is shown in Figure 3, and the unconfined compressive test piece damage image is shown in Figure 4.

\section{Results and Discussion}

3.1. CBR Text. The CBR test values of soil samples at different degrees of compaction are shown in Table 6.

It can be seen from the analysis in Table 6 that the CBR test value of silt sand increases with the increase in compaction degree, the CBR value and compaction degree of silty sand roadbed change linearly [25], and the CBR test value of cement-improved soil increases with the degree of compaction increasing significantly; in particular, the improved soil sample 1 was the most obvious. For every $1 \%$ increase in the degree of compaction, the CBR value increased by about $20 \%$, while the improved soil sample 2 increased with each $1 \%$ increase in the degree of compaction. The CBR value is increased by about 5\%. In the "Specifications for Design of Highway Subgrades" (JTG D30-2015) [26], the minimum load-bearing ratio of the filler is required to be no less than $8 \%$. The CBR test values of the two types of cement-modified silt sands are far greater than the CBR test values required in the subgrade design code, which meets the actual needs of the project.

3.2. Influence of the Soil Sample on Strength of CementModified Soil. 3\%, 4\%, 5\%, and 6\% cement is used, and the curing age is 7 days according to the standard. Eight groups of unconfined compressive tests are designed, and the unconfined compressive strength of different soil samples is shown in Table 7.

It can be seen from Table 7 that the unconfined compressive strength of soil sample 2 with different cement contents is higher than that of soil sample 1 and the unconfined compressive strength of $3 \%, 4 \%, 5 \%$, and $6 \%$ cement dosage is $73 \%, 63 \%, 73 \%$, and $75 \%$ higher, respectively. For analysis reason, according to particle analysis, soil sample 2 has large particle size, uniform particle distribution, and easy compaction, which can achieve better compaction effect and better integrity after compaction. 


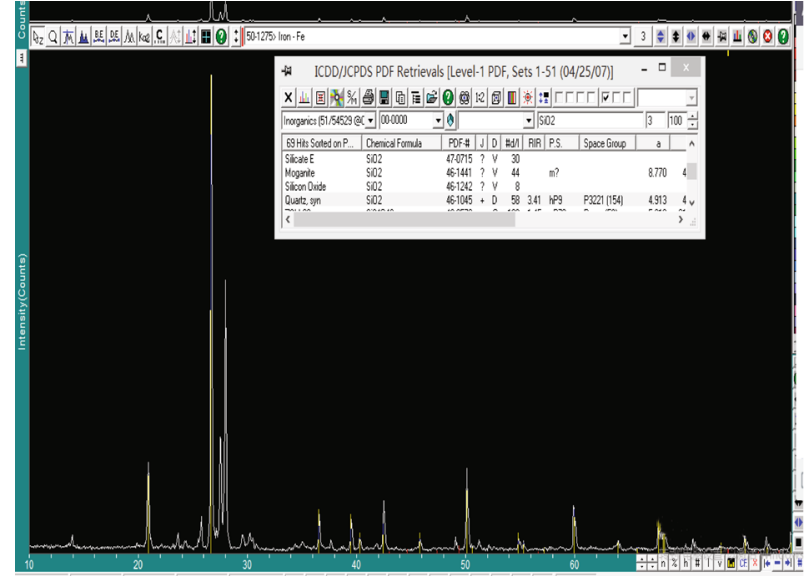

(a)

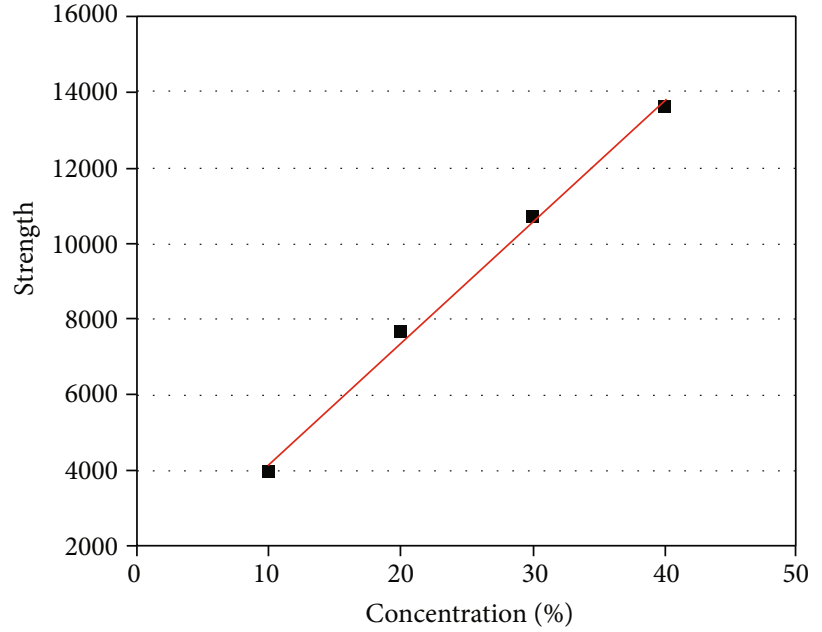

(b)

FIGURE 2: Chemical composition analysis process: (a) test soil sample contains $\mathrm{SiO}_{2}$; (b) $\mathrm{SiO}_{2}$ standard curve line. XRD spectrum analysis of different soil samples.

TABLE 4: Chemical composition analysis table.

\begin{tabular}{|c|c|c|c|c|c|c|}
\hline Chemical composition & $\mathrm{SiO}_{2}$ & $\mathrm{CaO}$ & $\mathrm{MgO}$ & $\mathrm{Fe}_{2} \mathrm{O}_{3}$ & $\mathrm{FeO}$ & $\mathrm{Al}_{2} \mathrm{O}_{3}$ \\
\hline Soil sample 1 & $81.39 \%$ & $0.69 \%$ & $0.32 \%$ & $0.62 \%$ & $1.22 \%$ & $7.39 \%$ \\
\hline Soil sample 2 & $84.45 \%$ & $1.04 \%$ & $0.40 \%$ & $0.71 \%$ & $1.50 \%$ & $9.02 \%$ \\
\hline Chemical composition & $\mathrm{TiO}_{2}$ & $\mathrm{P}_{2} \mathrm{O}_{5}$ & $\mathrm{~K}_{2} \mathrm{O}$ & $\mathrm{Na}_{2} \mathrm{O}$ & $\mathrm{MnO}$ & Los \\
\hline Soil sample 1 & $0.19 \%$ & $0.1 \%$ & $2.53 \%$ & $1.17 \%$ & $0.04 \%$ & $1.42 \%$ \\
\hline Soil sample 2 & $0.19 \%$ & $0.08 \%$ & $2.65 \%$ & $1.55 \%$ & $0.03 \%$ & $1.42 \%$ \\
\hline
\end{tabular}

TABLE 5: Test scheme of cement-modified soil.

\begin{tabular}{llccc}
\hline Soil sample & Water quality & Cement mixing amount (\%) & Curing age (d) & Test item \\
\hline Soil sample 1 & Drinking water/soaking water & $3,4,5,6$ & $7,14,28,90,180$ & Unconfined compressive strength \\
Soil sample 2 & Drinking water/soaking water & $3,4,5,6$ & $7,14,28,90,180$ & Unconfined compressive strength \\
Mixed soil sample & Drinking water/soaking water & 3,5 & 7 & Unconfined compressive strength \\
\hline
\end{tabular}
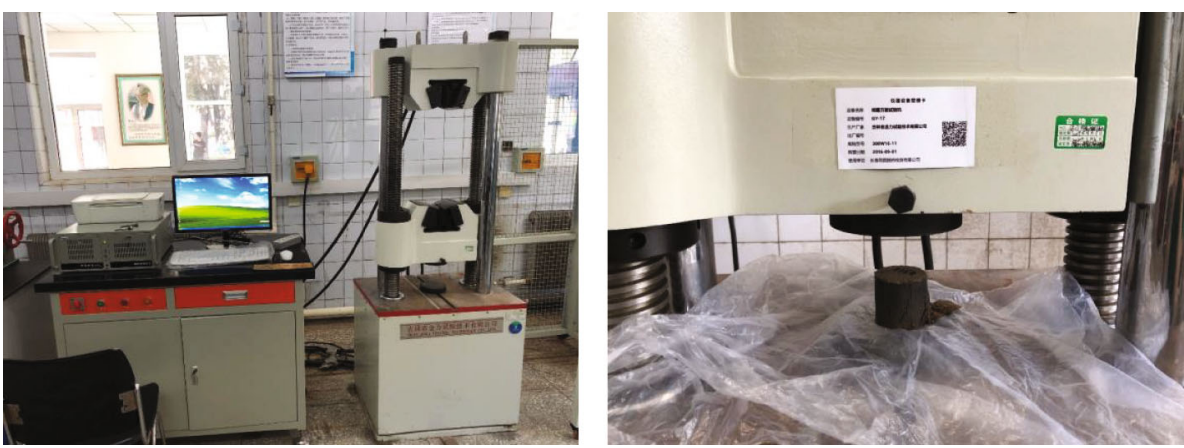

Figure 3: Unconfined compression test instrument.

The complex chemical reaction between soil particles and cement can be roughly divided into hydrolysis and hydration reactions, hardening reactions, ion exchange, carbonation, and crystallization. The main reason for improving the strength of silty sand after improvement is that the hydration reaction of cement produces a series of hydrates such as hydrated calcium silicate [27]. Hydrate has a cementing effect, which tightly wraps and connects soil particles, and forms a cement-stone skeleton in the voids of the soil particles $[28,29]$, reducing the plasticity of the soil and improving the strength of the cement-modified soil. Cement hardening reaction contributes the most to the later strength growth of cement-modified soil [6]. During the hardening reaction, $\mathrm{SiO}_{2}\left(\mathrm{Al}_{2} \mathrm{O}_{3}\right)$ reacts to form water-insoluble stable 


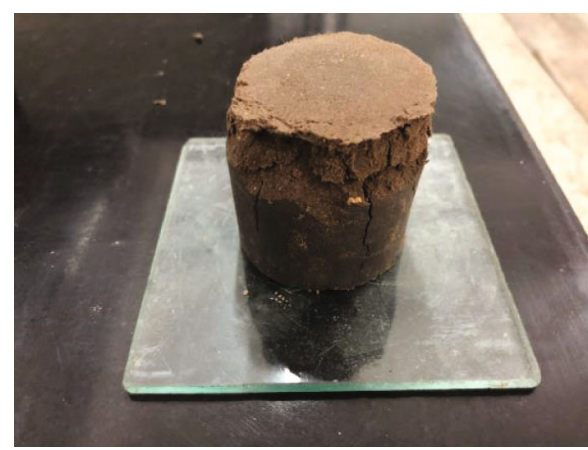

(a)

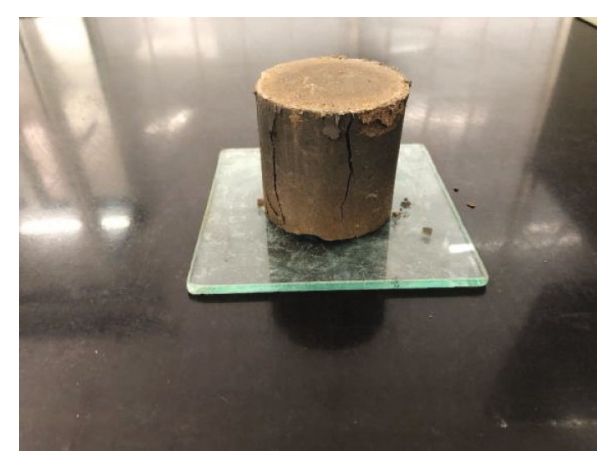

(b)

FIGURE 4: Destruction image of unconfined compression specimen: (a) plain soil; (b) cement-modified soil (mixed with 3\%).

TABLE 6: CBR test value.

\begin{tabular}{lcccc}
\hline \multirow{2}{*}{ Compactness (\%) } & \multicolumn{3}{c}{ CBR test values of different soil samples (\%) } \\
& Soil sample 1 & Soil sample 2 & Cement-modified soil sample 1 & Cement-modified soil sample 2 \\
\hline 93 & 15.1 & 13 & 76.1 & 114.7 \\
94 & 19.9 & 15.5 & 95.9 & 121.3 \\
96 & 29.6 & 20.5 & 135.6 & 134.5 \\
\hline
\end{tabular}

TABLE 7: Unconfined compressive strength table of different soil samples.

\begin{tabular}{|c|c|c|c|c|}
\hline $\begin{array}{l}\text { Soil } \\
\text { sample }\end{array}$ & $\begin{array}{c}\text { Cement } \\
\text { dosage }(\%)\end{array}$ & $\begin{array}{c}\text { Average } \\
\text { value }(\mathrm{MPa})\end{array}$ & $\begin{array}{l}\text { Standard } \\
\text { deviation }\end{array}$ & $\begin{array}{c}\text { Deviation } \\
\text { coefficient (\%) }\end{array}$ \\
\hline $\begin{array}{l}\text { Soil } \\
\text { sample } \\
1\end{array}$ & 3 & 0.26 & 0.07 & 0.25 \\
\hline $\begin{array}{l}\text { Soil } \\
\text { sample } \\
2\end{array}$ & 3 & 0.45 & 0.12 & 0.27 \\
\hline $\begin{array}{l}\text { Soil } \\
\text { sample } \\
1\end{array}$ & 4 & 0.30 & 0.08 & 0.28 \\
\hline $\begin{array}{l}\text { Soil } \\
\text { sample } \\
2\end{array}$ & 4 & 0.49 & 0.13 & 0.27 \\
\hline $\begin{array}{l}\text { Soil } \\
\text { sample } \\
1\end{array}$ & 5 & 0.38 & 0.16 & 0.41 \\
\hline $\begin{array}{l}\text { Soil } \\
\text { sample } \\
2\end{array}$ & 5 & 0.66 & 0.11 & 0.16 \\
\hline $\begin{array}{l}\text { Soil } \\
\text { sample } \\
1\end{array}$ & 6 & 0.49 & 0.09 & 0.18 \\
\hline $\begin{array}{l}\text { Soil } \\
\text { sample } \\
2\end{array}$ & 6 & 0.86 & 0.21 & 0.24 \\
\hline
\end{tabular}

calcium silicate and other crystalline compounds, also known as microcrystalline gels [30]. Reaction equations are shown in equations (1) and (2), and it continuously hardens in water, which improves the strength of the cementmodified soil and makes the structure more compact, mak- ing it difficult for water to penetrate and improving the water stability of the cement-modified soil [31]. From the analysis of the chemical composition of the soil sample, it can be seen that the $\mathrm{SiO}_{2}$ content of the chemical composition of the silt sand is very high, the $\mathrm{SiO}_{2}$ content of soil sample 1 accounts for $81.39 \%$ of the total, and the $\mathrm{SiO}_{2}$ content of soil sample 2 accounts for $84.45 \%$ of the total. The $\mathrm{Al}_{2} \mathrm{O}_{3}$ content of soil sample 1 accounts for $7.39 \%$ of the total, and the $\mathrm{Al}_{2} \mathrm{O}_{3}$ content of soil sample 2 accounts for $9.02 \%$ of the total. The hardening reaction of soil sample 2 is more sufficient. Therefore, the strength of soil sample 2 should be greater than that of soil sample 1. The analytical results are in good agreement with the experimental data.

$$
\begin{gathered}
\mathrm{SiO}_{2}+\mathrm{Ca}(\mathrm{OH})_{2}+\mathrm{nH}_{2} \mathrm{O} \longrightarrow \mathrm{CaO} \cdot \mathrm{SiO}_{2} \cdot(n+1) \mathrm{H}_{2} \mathrm{O} \\
\mathrm{Al}_{2} \mathrm{O}_{3}+\mathrm{Ca}(\mathrm{OH})_{2}+n \mathrm{H}_{2} \mathrm{O} \longrightarrow \mathrm{CaO} \cdot \mathrm{Al}_{2} \mathrm{O}_{3} \cdot(n+1) \mathrm{H}_{2} \mathrm{O}
\end{gathered}
$$

3.3. Influence of Water Quality on Strength of CementModified Soil. The influence of the alkalinity of water quality on unconfined compressive strength was explored by the control variable method. The curing period is 7 days, and eight groups of indoor unconfined compressive tests were conducted, with the data shown in Table 8 .

According to the data in Table 8, under the same cement dosage of the same soil sample, the maximum difference in unconfined compressive strength of different water qualities is $0.07 \mathrm{MPa}$ and the minimum is only $0.04 \mathrm{MPa}$. When the cement dosage is $3 \%$, the difference in unconfined compressive strength of mixed soil samples with different water qualities is $0.01 \mathrm{MPa}$, and when the cement dosage is $5 \%$, the difference in unconfined compressive strength of mixed soil 
TABLE 8: Influence of water quality on unconfined compressive strength.

\begin{tabular}{lccccc}
\hline Soil sample & Cement dosage (\%) & Water quality & Average value (MPa) & Standard deviation & Deviation coefficient (\%) \\
\hline Soil sample 1 & 3 & Drinking water & 0.26 & 0.07 & 0.25 \\
Soil sample 1 & 3 & Soaking water & 0.30 & 0.06 & 0.18 \\
Soil sample 2 & 3 & Drinking water & 0.45 & 0.12 & 0.27 \\
Soil sample 2 & 3 & Soaking water & 0.52 & 0.14 & 0.27 \\
Mixed soil sample & 3 & Drinking water & 0.32 & 0.08 & 0.25 \\
Mixed soil sample & 3 & Soaking water & 0.33 & 0.10 & 0.30 \\
Mixed soil sample & 5 & Drinking water & 0.58 & 0.09 & 0.20 \\
Mixed soil sample & 5 & Soaking water & 0.60 & 0.10 & 0.19 \\
\hline
\end{tabular}

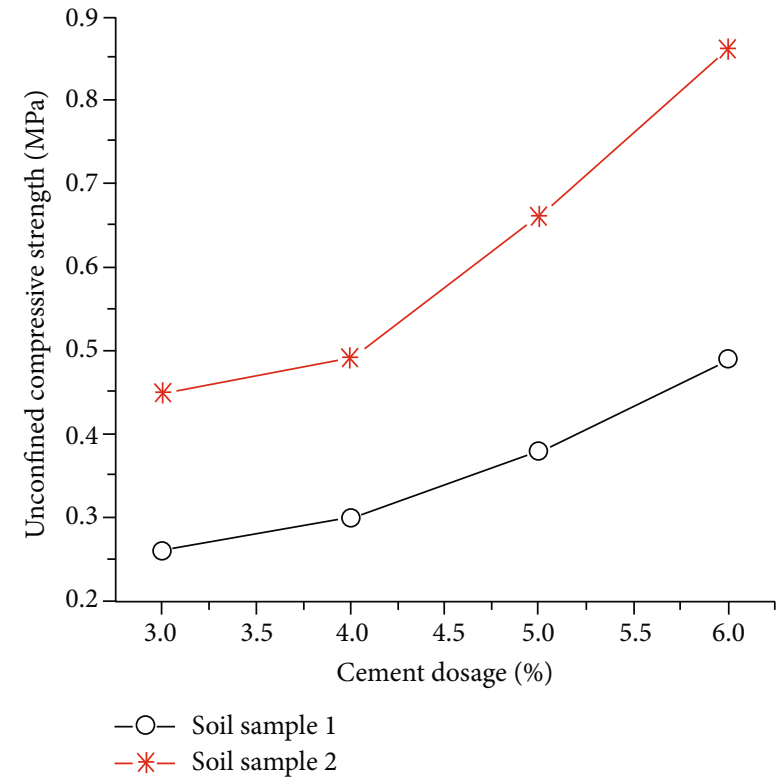

FIgURE 5: Unconfined compressive strength of silty sand with different cement dosages.

samples with different water qualities is $0.02 \mathrm{MPa}$. After multiple sets of test data analysis, the unconfined compressive strength data of different water qualities are similar. It can be seen that drinking water and alkaline immersion water have little effect on the unconfined compressive strength.

3.4. Influence of Cement Content on Strength of CementModified Soil. Eight groups of unconfined compressive tests were conducted with different cement contents of $3 \%, 4 \%$, $5 \%$, and $6 \%$ and curing age of 7 days. The statistical test data is shown in Figure 5.

Using the least square method to fit the curve, the power function relationship between cement dosage and unconfined compressive strength of two soil samples is constructed as follows:

Soil sample 1:

$$
R_{\mathrm{C}}=0.0913 C^{0.9074} \quad R^{2}=0.9514
$$

Soil sample 2:

$$
R_{\mathrm{C}}=0.1482 C^{0.9443} \quad R^{2}=0.9112
$$

where $C$ is the cement dosage and $R_{C}$ is the unconfined compressive strength.

It can be seen from equations (3) and (4), the correlation coefficients of the fitting relationship between soil sample 1 and soil sample 2 are both greater than 0.9 and close to 1 , which indicates that the fitting effect of the above two power function relationships is better. Through the analysis of the power function fitting curve, it is concluded that with the increase in cement content, the unconfined compressive strength keeps increasing and finally tends to a stable value, and the strength growth speed gradually slows down. The water-cement ratio of soil sample 1 with $3 \%, 4 \%, 5 \%$, and $6 \%$ cement content is $2.3,1.742,1.407$, and 1.184 . The water-cement ratio of soil sample 2 with $3 \%, 4 \%, 5 \%$, and $6 \%$ cement content is $2.781,2.106,1.701$, and 1.431 , and the corresponding relationship between the water-cement ratio and cement dosage is shown in Figure 6 . With the increase in cement content, the water-cement ratio of cement-modified soil decreases.

3.5. Effect of Curing Age on Unconfined Compressive Strength. To explore the influence of curing age on unconfined compressive strength, ten groups of unconfined compressive strength specimens were made by selecting different soil samples with a cement content of $3 \%$, which were cured for $7 \mathrm{~d}, 14 \mathrm{~d}, 28 \mathrm{~d}, 90 \mathrm{~d}$, and $180 \mathrm{~d}$, respectively, according to the specifications.

The unconfined compressive strength of soil sample 1 after curing for 7 days, 14 days, 28 days, 90 days, and 180 days is $0.26 \mathrm{MPa}, 0.52 \mathrm{MPa}, 0.67 \mathrm{MPa}, 1.05 \mathrm{MPa}$, and $1.18 \mathrm{MPa}$, respectively. The unconfined compressive strength of soil sample 2 is $0.45 \mathrm{MPa}, 0.69 \mathrm{MPa}, 0.88 \mathrm{MPa}$, $1.48 \mathrm{MPa}$, and $1.65 \mathrm{MPa}$ after 7 days, 14 days, 28 days, 90 days, and 180 days, respectively. From the above data, it can be known that the unconfined compressive strength of cement-modified soil increases with the increase in age. The growth rate of unconfined compressive strength is greater during the 7-14 days of the regimen period, and the growth rate of unconfined compressive strength gradually tends to be flat after 28 days. Using origin software to fit the average value of unconfined compressive strength and curing age, the functional relationship is as follows:

Cement-modified soil sample 1:

$$
P=0.2841 N-0.2646 ; R^{2}=0.9923 \text {. }
$$




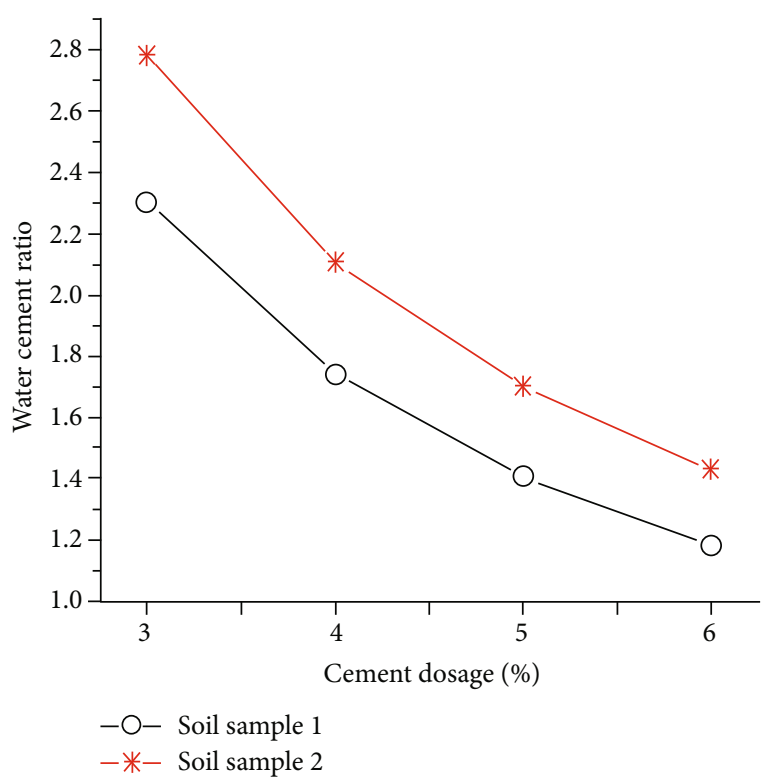

Figure 6: Water-cement ratio of different cement dosages.

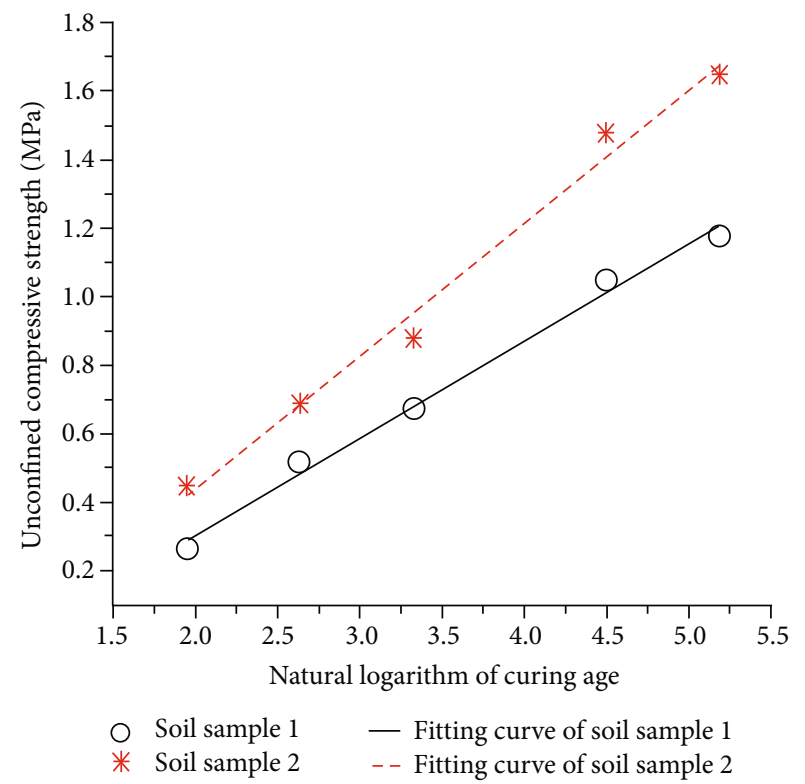

FIGURE 7: Relationship between different curing ages and unconfined compressive strength.

Cement-modified soil sample 2:

$$
P=0.3858 N-0.3287 ; R^{2}=0.9881,
$$

where $P$ is the unconfined compressive strength of the specimen (in $\mathrm{MPa}$ ) and $N$ is the natural logarithm of the curing age of the specimen (in days). The schematic diagram of the functional relationship is shown in Figure 7. From equations (5) and (6), it can be seen that the correlation coefficients of the two sets of soil sample fitting curves are high, both close to 1 , indicating that the strength of cement-modified soil has a good linear relationship with the logarithm of the curing age. The growth rate of unconfined compressive strength of soil sample 2 is greater than that of soil sample 1 .

3.6. Comprehensive Characterization Parameters of Strength of Cement-Modified Silty Sand. Based on the above test results, a new comprehensive characterization parameter PCT is constructed as shown in equation (7), which comprehensively reflects the influence of the soil sample, cement content, water-cement ratio, and curing age on the unconfined compressive strength:

$$
\mathrm{PCT}=\frac{w_{\mathrm{c}}}{a_{\mathrm{w}} \ln T}
$$

where $w_{\mathrm{c}}$ is the water cement ratio, $a_{\mathrm{w}}$ is the cement content (\%), and $T$ is the curing age (d). Figure 8 shows the relationship between unconfined compressive strength of cementmodified soil and comprehensive characterization parameter PCT. It can be seen from Figure 8 that the strength of different soil samples has a good power function relationship with characterization parameters, and their correlation coefficients are all above 0.90 . When the curing age is 7 days, the correlation coefficient is 0.91 for soil sample 1 and 0.95 for soil sample 2 . When the curing age is 14 days, the correlation coefficient is 0.94 for soil sample 1 and 0.92 for soil sample 2. When the curing age is 28 days, the correlation coefficient is 0.91 for soil sample 1 and 0.93 for soil sample 2. It shows that PCT can describe more than $90 \%$ strength factors of cement-improved silt, and the existing test data verify the validity of PCT.

Through the above regression analysis, the unconfined compressive strength of cement-improved silty sand can be expressed by the following empirical formula:

$$
f_{\mathrm{cu}}=A \cdot \mathrm{PCT}^{-B}
$$

where $A$ and $B$ are empirical parameters (positive values), which are generally related to soil properties and can be obtained by experience or test [21]. It can be seen from formulas (7) and (8) that the strength of cement-modified soil can be achieved by reducing the water-cement ratio, increasing the cement content, and prolonging the curing age. In engineering projects, the above parameters can be selectively optimized according to the field conditions to meet the requirements of subgrade strength in practical engineering.

\section{Conclusions}

The effects of compaction degree, different soil qualities, different water qualities, cement content, and curing age on the strength of cement-improved silty sand were studied by experiments, and the following main conclusions were obtained according to the test results:

(1) The CBR test value of cement-improved soil meets the requirements of engineering specifications and increases significantly with the increase in compaction. For every $1 \%$ increase in compaction of cement-improved soil sample 1, the CBR value 


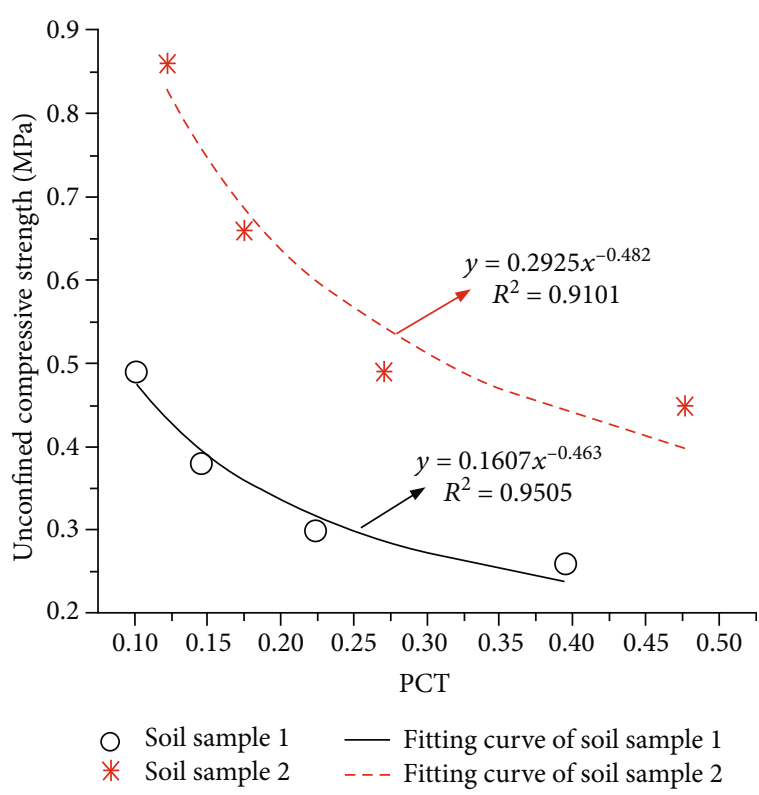

(a)

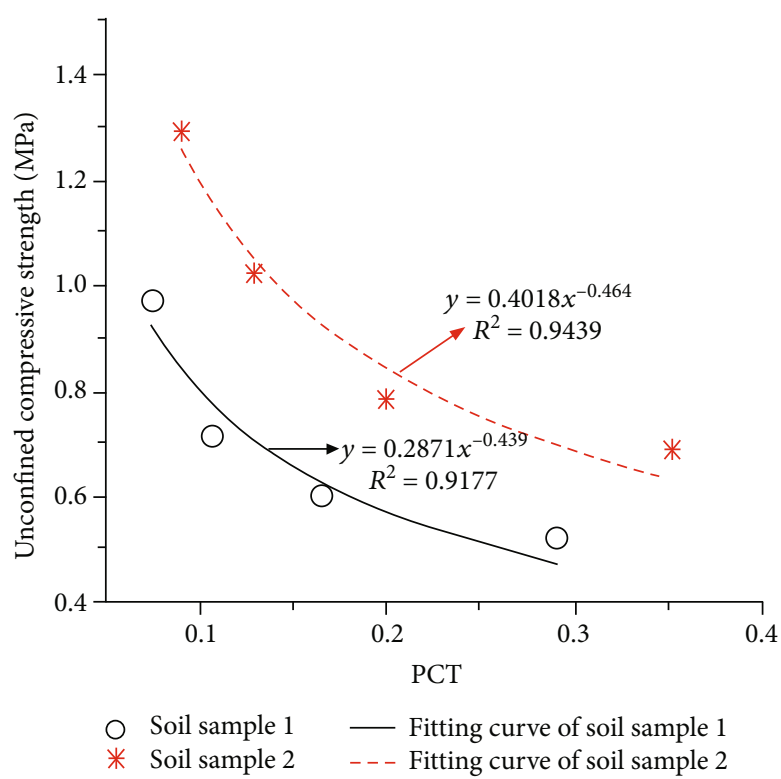

(b)

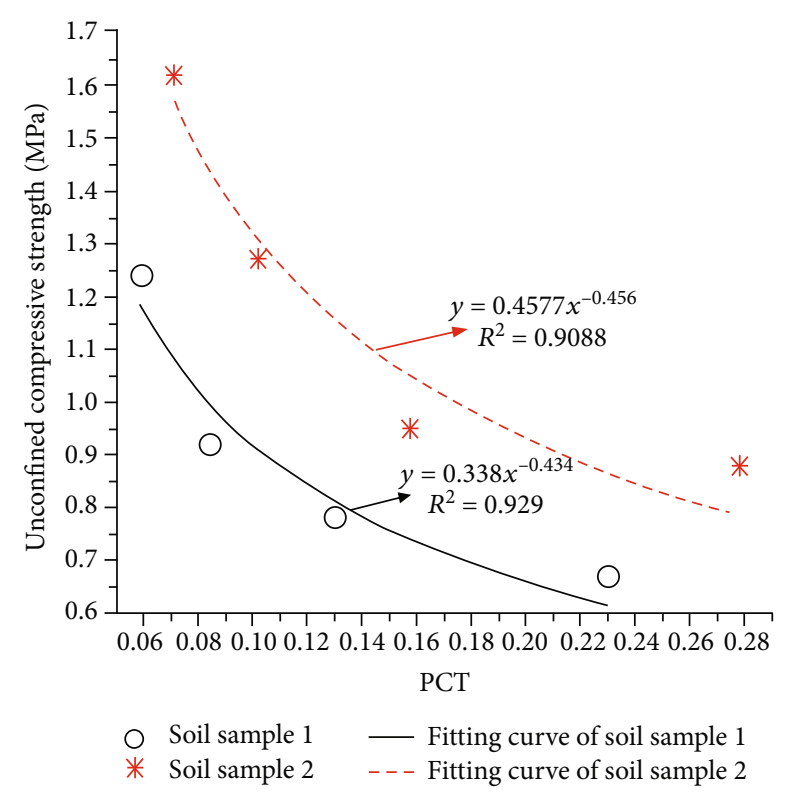

(c)

FIGURE 8: Relationship between unconfined compressive strength and PCT: (a) the curing age is 7 days; (b) the curing age is 14 days; (c) the curing age is 28 days.

increases by about 20\%; in cement-improved soil sample 2, when the degree of compaction increases by $1 \%$, the CBR value increases by about $5 \%$

(2) Under the same cement content and curing age, the unconfined compressive strength of cementimproved soil sample 2 is $63 \%-75 \%$ higher than that of cement-modified soil sample 1 . The reason is that the silt sand with large particle size and uniform particle distribution can achieve better compaction effect and better integrity after compaction. The silica content of different soil samples is more than $80 \%$, and soil sample 2 is greater than soil sample
1. The cement-modified soil generates microcrystalline gel during the hardening reaction, which improves the strength of the cement-modified soil and makes the structure more compact

(3) Drinking water and alkaline immersion water have little effect on the unconfined compressive strength of cement-modified soil. As the cement content increases, the cement-modified soil decreases the water-cement ratio and increases the unconfined compressive strength. The strength of cementmodified soil increases approximately in a power function relationship with the increase in the cement 
content. The logarithmic relationship between cement-soil strength and curing age is approximately linear, the unconfined compressive strength of cement-improved silty sand increases the fastest in 7-14 days of curing age, and the strength growth rate tends to be flat after 28 days. In the same curing time, the unconfined compressive strength of soil sample 2 increased faster than that of soil sample 1

(4) The established comprehensive characterization parameter PCT can better reflect the influence of the water-cement ratio, cement content, curing age, and other factors on the unconfined compressive strength of cement-improved soil. The strength of cement-improved soil has a good power function relationship with the comprehensive characterization parameter PCT. This relationship can be used to predict the strength of cement-improved soil in actual engineering

\section{Data Availability}

The experimental data used to support the findings of this study are included within the article.

\section{Conflicts of Interest}

The authors declare that there are no conflicts of interest regarding the publication of this paper.

\section{References}

[1] H. Rui, C. Sili, X. Ma, Y. Hu, and J. Guolong, "Study on mechanical properties of iron tailings cement composite soil," Sino-foreign Highway, vol. 39, no. 1, pp. 206-209, 2019.

[2] Q. Lu, S. Gu, M. Wa, and G. Meng, "Experimental study on mechanical properties of fiber cement soil," Rock and Soil Mechanics, vol. 37, no. S2, pp. 421-426, 2016.

[3] W. Pengyun, Y. Yongliang, W. Linhao, and B. Xiaohong, "Effect of metakaolin on strength and permeability coefficient of cemented soil," Science Technology and Engineering, vol. 18, no. 10, pp. 112-116, 2018.

[4] Z. Hailong, X. Shen, and H. Xue, "Experimental study on unconfined compressive strength of small age cement soil," Journal of Shandong University (Engineering Science), vol. 44, no. 1, pp. 75-79, 2014.

[5] S. Shuang, Study on Mechanical Properties of Subgrade Cement Modified Silty Sand in Seasonal Frozen Area, Jilin Jianzhu University, 2019.

[6] B. Yang, Study on the Strength Law of Cement-Soil, Shanghai Jiaotong University, Shanghai, 2007.

[7] C. Weichao and W. Yang, "Experimental study on unconfined compressive strength of sand improved by cement," Chinese and Foreign Highway, vol. 39, no. 6, pp. 188-196, 2019.

[8] L. Songyu, Q. Guochao, and Z. Dingwen, "Theory and engineering application of DJM pile composite foundation," Rock and Soil Mechanics, vol. 2, p. 363, 2007.

[9] L. Yonghui, H. Haixia, and M. Lele, "Experimental study on unconfined compressive strength of Zhengzhou silt cement soil," Highway, vol. 64, no. 5, pp. 209-213, 2019.
[10] L. Jie and H. Zhijun, "Experimental study on mechanical properties of cement-modified silt under dry and wet environment," Railway Construction, vol. 11, pp. 84-87, 2012.

[11] Y. Shengcai, "Experimental study on physical and mechanical properties of cement-improved soil," Railway Architecture, vol. 4, pp. 107-109, 2015.

[12] C. Junyan, "Study on influencing factors of unconfined compressive strength of cement stabilized soil," Subgrade Engineering, vol. 6, pp. 150-153, 2018.

[13] X. Zhang, E. Zhai, Y. Wu, D.'. Sun, and Y. Lu, "Theoretical and numerical analyses on hydro-thermal-salt-mechanical interaction of unsaturated salinized soil subjected to typical unidirectional freezing process," International Journal of Geomechanics, vol. 21, no. 7, article 04021104, 2021.

[14] X. Zhang, Y. Wu, E. Zhai, and P. Ye, "Coupling analysis of the heat-water dynamics and frozen depth in a seasonally frozen zone," Journal of Hydrology, vol. 593, article 125603, 2021.

[15] Y. Wu, E. Zhai, X. Zhang, G. Wang, and Y. Lu, "A study on frost heave and thaw settlement of soil subjected to cyclic freeze- thaw conditions based on hydro-thermal-mechanical coupling analysis," Cold Regions Science and Technology, vol. 188, article 103296, 2021.

[16] C. Y. Liu, Y. Wang, X. M. Hu, Y. L. Han, X. P. Zhang, and L. Z. du, "Application of GA-BP neural network optimized by grey Verhulst model around settlement prediction of foundation pit," Geofluids, vol. 2021, Article ID 5595277, 16 pages, 2021.

[17] Y. Xu, Y. Wu, X. Zhang, and G. Chen, "Effects of freeze-thaw and chemical preconditioning on the consolidation properties and microstructure of landfill sludge," Water Research, vol. 200, article 117249, 2021.

[18] Y. J. Wu, Y. Xu, X. Zhang et al., "Experimental study on vacuum preloading consolidation of landfill sludge conditioned by Fenton's reagent under varying filter pore size," Geotextiles and Geomembranes, vol. 49, no. 1, pp. 109-121, 2021.

[19] G. A. Lorenzo and D. T. Bergado, "Fundamental parameters of cement-admixed clay-new approach," Journal of Geotechnical and Geoenvironmental Engineering, vol. 130, no. 10, pp. 1042-1050, 2004.

[20] C. Chengfu, H. Zhenshun, L. Songyu, and T. Xu, "Prediction of unconfined compressive strength of cement-soil by watercement ratio," Rock and Soil Mechanics, vol. 4, pp. 645-649, 2005.

[21] C. Zhiguo and Z. Dingwen, "Study on characterization parameters of unconfined compressive strength of cement-soil," Journal of Rock Mechanics and Engineering, vol. 34, no. S1, pp. 3446-3454, 2015.

[22] Research Institute of Highway Science, Ministry of Transport, Test Methods of Soils for Highway Engineering: JTG 3430-2020, People's Communications Press, 2020.

[23] Highway Research Institute of the Ministry of Communications, Test Methods of Materials Stabilized with Inorganic Binders for Highway Engineering: JTG E51-2009, People's Communications Press, 2009.

[24] China Communications Highway Planning and Design Institute Co, Ltd, Specifications for Design of Foundation of Highway Bridges and Culverts, People's Communications Press, 2019.

[25] Z. Yongwei, Experimental Study on Road Performance of Silt Subgrade of Highway Runway, Zhengzhou University, 2012. 
[26] CCCC Second Highway Survey, Design and Research Institute, Specifications for Design of Highway Subgrades: JTG D30-2015, People's Communications Publishing House, 2015.

[27] L. Lihan, Road Engineering Materials, People's Communications Publishing House, 2010.

[28] Z. Xiangdong, L. Jun, S. Qi, F. Yi, L. Jiashun, and Q. Zhi, "Research on dynamic performance and rheological characteristics of cement-improved aeolian sand under negative temperature," Rock and Soil Mechanics, vol. 39, no. 12, pp. 4395-4403+4412, 2018

[29] C. Liu, X. Hu, R. Yao et al., "Assessment of soil thermal conductivity based on BPNN optimized by genetic algorithm," Advances in Civil Engineering, vol. 2020, Article ID 6631666, 10 pages, 2020.

[30] Z. Guirong, Z. Luo, S. Yong, Z. Xinjie, and F. Wang, "Engineering characteristics and improvement mechanism of fine sands improved by cement and fly ash," Journal of Water Resources and Architectural Engineering, vol. 17, no. 5, pp. 128-132, 2019.

[31] Y. Yong, Experimental Study on Improving the Mechanical Properties of Cement-Soil with Glass Fiber, Southeast University, 2006. 